International Journal of Current Microbiology and Applied Sciences ISSN: 2319-7706 Volume 7 Number 04 (2018)

\title{
In vitro Evaluation of the Curcumin against Fluconazole-Resistant Strains of Candida spp. and Cryptococcus neoformans
}

Daniel Domingues Freitas ${ }^{1}$, Cecília Rocha da Silva ${ }^{1,2}$, João Batista de Andrade Neto ${ }^{1}$, Rosana de Sousa Campos ${ }^{1,2}$, Letícia Serpa Sampaio ${ }^{1}$, Francisca Bruna Stefany Aires do Nascimento $^{1}$, Maria Aparecida Alexandre Josino ${ }^{1}$, Lisandra Juvêncio da Silva ${ }^{1}$, Helaine Almeida Queiroz ${ }^{1}$, Fátima D. D. Barroso ${ }^{1}$, Jacó R. L. Mesquita ${ }^{3}$, Thalles Barbosa Granjeiro $^{4}$, Said Gonçalves da Cruz Fonseca ${ }^{5}$, Bruno Coêlho Cavalcanti ${ }^{6}$, Manoel Odorico de Moraes ${ }^{6}$ and Hélio Vitoriano Nobre Júnior ${ }^{*}$

${ }^{1}$ Department of Clinical and Toxicological Analysis, School of Pharmacy, Laboratory of Bioprospection in Antimicrobial Molecules (LABIMAN), Federal University of Ceará, Fortaleza, CE, Brazil

${ }^{2}$ Christus University Center (UNICHRISTUS), Fortaleza, CE, Brazil

${ }^{3}$ São José Hospital, Fortaleza, CE, Brazil

${ }^{4}$ Department of Biology, Science Center, Molecular Genetics Laboratory, Federal University of Ceara, CE, Brazil

${ }^{5}$ School of Pharmacy, Federal University of Ceara, Fortaleza, CE, Brazil

${ }^{6}$ Department of Physiology and Pharmacology, Federal University of Ceara, Fortaleza, CE, Brazil

*Corresponding author

\section{Keywords}

Curcumin. Resistance.

Fluconazole. Candida. Cryptococcus neoformans

Article Info

Accepted:

10 March 2018

Available Online:

10 April 2018

\section{A B S T R A C T}

The isolates of Candida spp. and Cryptococcus neoformans were inhibited by curcumin, with different degrees of inhibition among species, with MICs ranging from 8-64 $\mu \mathrm{g} / \mathrm{mL}$. After exposure of the C. albicans strains to curcumin, it was observed a decrease in the number of viable cells and damage to cell membranes, the mitochondrial function of $C$. albicans cells appears to be affected after exposure to curcumin. Our data suggest that after exposure to curcumin, $C$. albicans cells showed total strand breaks in the DNA, where the nuclear DNA fragmentation was evident in the comet assay. Oxidative damage to DNA was verified by the alkaline comet assay in the presence of Fpg, where it was observed an increase in DNA migration of cells that were treated with curcumin. Based on the characteristics of cell death observed, it is raised the hypothesis that curcumin seems to exert its antifungal activity at specific sites near the DNA, resulting in cell death by apoptosis. 


\section{Introduction}

Fungal infections caused by the genus Candida represent a concern in clinical medicine related to public health, because these infections show high prevalence in different medical centers, and also due to their complications, difficult diagnosis, in addition to being associated with mortality in the order of 30-50\% in children and adults (Nucci et al., 2013; Colombo et al., 2007).

The candidemias are considered the most common invasive mycoses, accounting for $80 \%$ of hospital fungal infections. Candida spp. is currently considered the fourth agent of bloodstream infections [representing 8-10\% of cases], due to a $500 \%$ increase in its incidence from the decade of 80 (Colombo et al., 2007; Bergamasco et al., 2013).

Other fungal infections of opportunistic character, which also represent a public health problem worldwide, affecting not only immunocompromised, but also immunocompetent individuals, are infections caused by the genus Cryptococcus (Del Poeta and Casadevall, 2012).

The Cryptococcus genus contains about 48 species, two being clinically relevant, Cryptococcus neoformans and Cryptococcus gattii. The scope of cryptococcosis by $C$. neoformans prevails when associated with low cellular immunity conditions. This characteristic is due to its tendency to infect immunocompromised individuals, particularly those infected with the Human Immunodeficiency Virus [HIV] (Del Poeta and Casadevall, 2012; Kronstad et al., 2011).

The antifungal resistance, especially to azolebased drugs, has emerged as a major clinical problem for immunosuppressed patients and hospitalized at high risk for fungal infections (Pfaller et al., 2012). Given the small pharmacological arsenal to antifungal treatments when compared to the arsenal of antibiotics, often studies look for new antifungals that have greater spectrum of action, low cost and lower evidence of antifungal resistance, considering that this is a current problem (Zhang et al., 2009).

In this context, herbal antifungal drugs have gained importance due to their natural origin. Curcumin has demonstrated its therapeutic potential with anti-inflammatory, antioxidant, antibacterial, antiparasitic action (Maheshwari et al., 2006), being also well documented in the treatment of breathing problems (Shaikh $e t$ al., 2009), in various chronic diseases presenting inflammation (Aggarwal and Harikumar, 2009), and the antifungal activity is another major biological effect of curcumin, in particular against Candida spp. (Khan et al., 2012; Martins, 2009).

The aim of the study was to evaluate the antifungal potential of curcumin against fluconazole-resistant strains of Candida spp. and Cryptococcus neoformans, elucidating the possible mechanisms involved in the cytotoxic action of curcumin through procedures such as flow cytometry and comet assay.

\section{Materials and Methods}

\section{Isolates}

We used nine fluconazole-resistant strains of Candida spp. (Ramos et al., 2016). Fluconazole-resistant $C$. albicans (three strains), $C$. tropicalis (three strains), $C$. parapsilosis (three strains) and Cryptococcus neoformans (four strains) clinical strains were used. These strains are from the yeast collection of the Laboratory of Bioprospection in Antimicrobial Molecules (LABIMAN/ FF/UFC). The strains were inoculated in Sabouraud dextrose agar (Himedia, Mumbai, India) and incubated at $37^{\circ} \mathrm{C}$ for $24 \mathrm{~h}$. Then, 
they were grown in CHROMagAar Candida (Himedia) to evaluate their purity.

\section{In vitro antifungal activity}

The drug was tested according to the document M27-A3 using RPMI broth (pH 7.0) buffered with 0.165 M MOPS (Sigma Chemical, St. Louis, MO). Fluconazole (Merck Sharp \& Dohme, São Paulo, Brazil) was dissolved in distilled water, and solution of curcumin chloride form (Sigma Chemical) was prepared in dimethylsulfoxide (DMSO; Sigma Chemical). Fluconazole (FLC) and curcumin were tested at concentrations ranging from 0.125 to $64 \mathrm{mg} / \mathrm{L}$. Yeasts and compounds were incubated in 96-well culture plates at $35^{\circ} \mathrm{C}$ for $24 \mathrm{~h}$ and the results were examined visually, as recommended by CLSI (2008). The following cut-off points were determined according to the document M27S4 (CLSI, 2012). The strains $C$. parapsilosis ATCC 22019 and C. krusei ATCC 6258 were used as control.

\section{Cell treatments}

To assess cell density, membrane integrity, mitochondrial transmembrane potential and DNA damage (comet assay), the fluconazoleresistant strain $C$. albicans was exposed for 24 $\mathrm{h}$ to increasing curcumine concentrations (MIC, 2x MIC, and 4x MIC). All tests were conducted in triplicate, in three independent experiments (Da Silva et al., 2013; Andrade Neto et al., 2014).

\section{Preparation of yeast suspensions}

Cell suspensions were prepared from cultures in the exponential growth phase. The cells were collected by centrifugation (1600 $g$ for $10 \mathrm{~min}$ at $4^{\circ} \mathrm{C}$ ), washed twice with a $0.85 \%$ saline solution $\left(1200 \mathrm{~g}\right.$ for $5 \mathrm{~min}$ at $\left.4^{\circ} \mathrm{C}\right)$ and then resuspended $\left(\sim 10^{6}\right.$ cells $\left./ \mathrm{mL}\right)$ in HEPES buffer ( $\mathrm{pH}$ 7.2) supplemented with $2 \%$ glucose. Amphotericin B (Ampho B; Sigma Chemical) was used as cell death control (Da Silva et al., 2013; Andrade Neto et al., 2014).

\section{Determination of cell density and membrane integrity}

Cell density and membrane integrity of fungal strains were evaluated by the exclusion of 2 $\mathrm{mg} / \mathrm{L}$ PI (propidium iodide). Aliquots from yeasts incubated for $24 \mathrm{~h}$ with the drugs (curcumin, FLC, Ampho B) were analysed using flow cytometry. 10,000 events were evaluated per experiment $(n=2)$ and the cellular debris was omitted from analysis. Cellular fluorescence was then determined by flow cytometry using a Guava EasyCyte ${ }^{\mathrm{TM}}$ Mini System cytometer (Guava Technologies Inc., Hayward, CA, USA) and analysed using CytoSoft 4.1 software (Da Silva et al., 2013; Andrade Neto et al., 2014).

\section{Measurement of mitochondrial transmembrane potential $[\Delta \psi \mathrm{m}]$}

The mitochondrial transmembrane potential was determined by measuring the retention of rhodamine 123 dye by the mitochondria of yeast cells after $24 \mathrm{~h}$ exposure. The cells were washed with $\mathrm{PBS}$, incubated with $5 \mathrm{mg} / \mathrm{L}$ rhodamine 123 at $37^{\circ} \mathrm{C}$ for $30 \mathrm{~min}$, in the dark, and then washed twice with PBS. Their fluorescence was measured by flow cytometry (Guava EasyCyte ${ }^{\mathrm{TM}}$ Mini System). A total of 10,000 events was evaluated per experiment $[\mathrm{n}=2]$ and cellular debris was omitted from analysis (Da Silva et al., 2013; Andrade Neto et al., 2014).

\section{Yeast comet assay}

This assay was performed essentially as described by Da Silva et al., (2016). For each experimental group, it was under analysis images obtained by fluorescence microscopy 
of 100 randomly selected cells (50 cells from each of 2 replicate slides). The cells were scored visually and depending on their tail size they were assigned to one of five classes (from undamaged [class 0] to maximally damaged [class 4]), and a damage index value was calculated for each sample of cells. The damage index values, thus, ranged from 0 (completely undamaged: 100 cells x 0) to 400 (maximum damage: 100 cells $\mathrm{x}$ 4). The tailed cells were taken as an indicator of DNA damage and its frequency was calculated based on the numbers of cells with tails (DNA strand breaks) and without them (Da Silva et al., 2016).

\section{Analysis of oxidized purine and pyrimidine bases in yeast DNA}

The alkaline comet assay was performed as described above. The slides were removed from the lysis solution and were washed three times in an enzyme buffer (40 mM HEPES, $100 \mathrm{mMKCl}, 0.5 \mathrm{mM}$ EDTA, and $0.2 \mathrm{mg} / \mathrm{mL}$ BSA, pH 8.0), drained and incubated with 70 $\mu \mathrm{L}$ of formamidopyrimidine DNA-glycosylase (FPG) for $30 \mathrm{~min}$ at $37^{\circ} \mathrm{C}$. Images of 100 randomly selected cells per group [50 cells from each of two replicate slides] were visually analysed. The number of oxidized purines (FPG-sensitive sites) was then determined by subtracting the amount of strand breaks observed in the control (samples incubated only with buffer) from the total amount of breaks obtained after incubation with FPG (Da Silva et al., 2013; Andrade Neto et al., 2014).

\section{Annexin V staining}

Treated and untreated $C$. albicans cells were collected by centrifugation and digested with 2 $\mathrm{mg} / \mathrm{mL}$ zymolyase 20T (Seikagaku Corp., Japan) in potassium phosphate buffer (PPB, 1 $\mathrm{M}$ sorbitol, $\mathrm{pH}$ 6.0) for $2 \mathrm{~h}$ at $30^{\circ} \mathrm{C}$. Protoplasts of $C$. albicans were stained with
FITC-labelled Annexin V and PI using a FITC-Annexin V apoptosis detection kit (Guava Nexin Kit, Guava Technologies, Inc., Hayward, CA, USA). Subsequently, the cells were washed with PPB and incubated in an Annexin binding buffer containing $5 \mu \mathrm{l} / \mathrm{ml}$ of FITC-Annexin V and $5 \mu \mathrm{l}$ of PI for $20 \mathrm{~min}$. The cells were then analyzed by flow cytometry (Guava EasyCyte ${ }^{\mathrm{TM}}$ Mini System). For each experiment $(n=2), 10,000$ events were evaluated, and cell debris was omitted from analysis (Andrade Neto et al., 2014).

\section{Statistical analysis}

In vitro susceptibility experiments were repeated at least three times on different days. Geometric means were used to compare MIC results. The data obtained from flow cytometry and alkaline comet assays were compared using a one-way analysis of variance [ANOVA] followed by NewmanKeuls test $(\mathrm{p}<0.05)$.

\section{Results and Discussion}

The sensitivity of each strain to fluconazole was assessed using the broth microdilution method (CLSI, 2008). According to table 1, after 24 hours of exposure to fluconazole, all tested strains showed MICs between 16 and $64 \mu \mathrm{g} / \mathrm{mL}$, thus confirming their resistance. When the strains in studies were treated with curcumin, varying degrees of inhibition between species were observed. Table 1 shows an antimicrobial activity against clinical isolates of yeasts, with MIC to Candida albicans (8 $\mu \mathrm{g} / \mathrm{mL})$, Candida parapsilosis $(8 \mu \mathrm{g} / \mathrm{mL})$, Candida tropicalis (8$32 \mu \mathrm{g} / \mathrm{mL}$ ) and Cryptococcus neoformans (8$64 \mu \mathrm{g} / \mathrm{mL})$.

Neelofar et al., (2011) show the antifungal properties of curcurmin against 14 strains of Candida spp., with MICs ranging from 250 to $2000 \mu \mathrm{g} / \mathrm{ml}$. Not withstanding, our results 
demonstrated much lower concentrations than the described above. In a study by Ludwing $e t$ al., (2013), curcumin was able to inhibit the growth of $C$. neoformans ATCC strains with MICs between 31.25-62.5 $\mu \mathrm{g} / \mathrm{ml}$. These data corroborate those of the present study, considering that the band was found between $8-64 \mathrm{mg} / \mathrm{ml}$.

Treatment of strains with fluconazole showed no DNA damage after 24 hours of exposition. As shown in Figure 5, curcumin promoted DNA damage in the cells of fluconazoleresistant $C$. albicans. Cells treated with curcumin exhibited percentage damage index of $22.50 \pm 5.04$ (MIC), $37.50 \pm 5.09$ (2x MIC) and $74.50 \pm 4.59$ ( $4 \mathrm{x}$ MIC), when compared to the control group $(10.50 \pm 4.08)(\mathrm{p}<0.05)$. It was also observed that $C$. albicans cells resistant to FLC, when incubated with the Fpg enzyme, showed a significant increase in the values of the damage index compared to the control group $(\mathrm{p}<0.05)$ after treatment with curcumin (Figure 6).

Lu et al., (2009) found that after 24 and $48 \mathrm{~h}$ of incubation at a concentration of 10, 25 and $30 \mu \mathrm{M}$, the compound curcumin led to increased DNA migration. According to Ogiwara et al., (2013), curcumin promotes the breakage of double-stranded DNA through inhibition of histone acetylation in DNA. According to Cao et al., (2007), curcumin at high doses $(\geq 10 \mu \mathrm{g} / \mathrm{ml})$ promotes damage to the nuclear DNA and to the mitochondrial DNA, leading the cell to trigger a process of cell death by apoptosis. In this study, curcumin showed breaks in DNA strands at doses greater than $8 \mu \mathrm{g} / \mathrm{ml}$, which corroborates the findings of the above authors.

Also according to Cao et al., (2007), the damage to nucleic acids caused by curcumin could be due to oxidative stress conditions. It is important to stand out that structural modification in the nucleotide bases may occur as a result of oxidative stress. Several studies point to the role of reactive oxygen species (ROS's) in the mechanism of action of curcumin (Kumar et al., 2014; Sharma et al., 2010).

The strain treatment with fluconazole $(24 \mathrm{~h}$ exposure) showed no externalization of phosphatidylserine. Cells treated with curcumin ( $24 \mathrm{~h}$ exposure) exhibited annexinpositive cell percentage of $8.89 \pm 2.21 \%$ (MIC) $21.61 \pm 5.42 \%(2 x$ MIC) and $46.74 \pm$ $5.46 \%$ (4x MIC) compared with the control group $(3.97 \pm 0.67 \%)(\mathrm{p}<0.05)$, according to Figure 4. Cell death by apoptosis is a peculiar suicide program characterized by the externalization of phosphatidylserine on the plasma membrane, the condensation of chromatin and fragmentation of DNA, mitochondrial damage and cytochrome c release from mitochondria to the cytosol (Sukhanova et al., 2012).

Curcumin demonstrated a significant reduction in the number of viable cells after different concentrations (MIC, 2x MIC and 4x MIC) (Figure 1). Moreover, curcumin has caused damage to the cell membrane of fluconazole-resistant $C$. albicans, as shown in Figure 2. According to the experiments of Azad et al., (2013), in mutant strains of Saccharomyces cerevisiae, the results of the viability test have suggested that the cells started to become metabolically inactive after treatment with curcumin.

Recently, Kumar et al., (2014) reported that after treatment with curcumin alone or associated with antifungal in $C$. albicans cells, there was an increase in the membrane permeabilization to the PI dye, which agrees with our results, where the fungal growth and the development and the ability to survive under environmental stress conditions are dependent on the integrity of the membrane and the cell wall. 
Table.1 Antifungal effect of curcumine against strains of yeast resistant to fluconazole and isolated in Ceará

\begin{tabular}{|c|c|c|}
\hline \multirow{2}{*}{ Strains $^{\mathrm{a}}$} & \multicolumn{2}{|c|}{ MIC $^{\mathrm{b}}$} \\
\hline & FLC & Curcumine \\
\hline C. albicans 1 (289) & $16 \mu \mathrm{g} / \mathrm{mL}$ & $8 \mu \mathrm{g} / \mathrm{mL}$ \\
\hline C. albicans 2 (442)* & $32 \mu \mathrm{g} / \mathrm{mL}$ & $8 \mu \mathrm{g} / \mathrm{mL}$ \\
\hline C. albicans 3 (103A) & $32 \mu \mathrm{g} / \mathrm{mL}$ & $8 \mu \mathrm{g} / \mathrm{mL}$ \\
\hline C. parapsilosis 1 (71A) & $32 \mu \mathrm{g} / \mathrm{mL}$ & $8 \mu \mathrm{g} / \mathrm{mL}$ \\
\hline C. parapsilosis 2 (356) & $32 \mu \mathrm{g} / \mathrm{mL}$ & $8 \mu \mathrm{g} / \mathrm{mL}$ \\
\hline C. parapsilosis 3 (271A) & $32 \mu \mathrm{g} / \mathrm{mL}$ & $8 \mu \mathrm{g} / \mathrm{mL}$ \\
\hline C. parapsilosis 4 (43) & $32 \mu \mathrm{g} / \mathrm{mL}$ & $8 \mu \mathrm{g} / \mathrm{mL}$ \\
\hline C. parapsilosis 5 (72A) & $32 \mu \mathrm{g} / \mathrm{mL}$ & $32 \mu \mathrm{g} / \mathrm{mL}$ \\
\hline C. parapsilosis 6 (848) & $16 \mu \mathrm{g} / \mathrm{mL}$ & $8 \mu \mathrm{g} / \mathrm{mL}$ \\
\hline C. parapsilosis 7 (423) & $16 \mu \mathrm{g} / \mathrm{mL}$ & $16 \mu \mathrm{g} / \mathrm{mL}$ \\
\hline C. tropicalis 1 (574A) & $16 \mu \mathrm{g} / \mathrm{mL}$ & $16 \mu \mathrm{g} / \mathrm{mL}$ \\
\hline
\end{tabular}

${ }^{a}$ FLC-resistant strains of yeast isolated from biological samples.

${ }^{\mathrm{b}}$ FLC - Fluconazole. The MIC was defined as the lowest concentration that produced a $50 \%$ reduction in growth of fungal cells after $24 \mathrm{~h}$ of incubation. The procedure was performed according to CLSI protocol M27-A3. Values are expressed in $\mu \mathrm{g} / \mathrm{mL}$ for FLC and Curcumine. MICs represent geometric means of at least three MICs determined on different day's ${ }^{c}$.

*The strains were used for determination of action mechanism.

Fig.1 The cell number viable

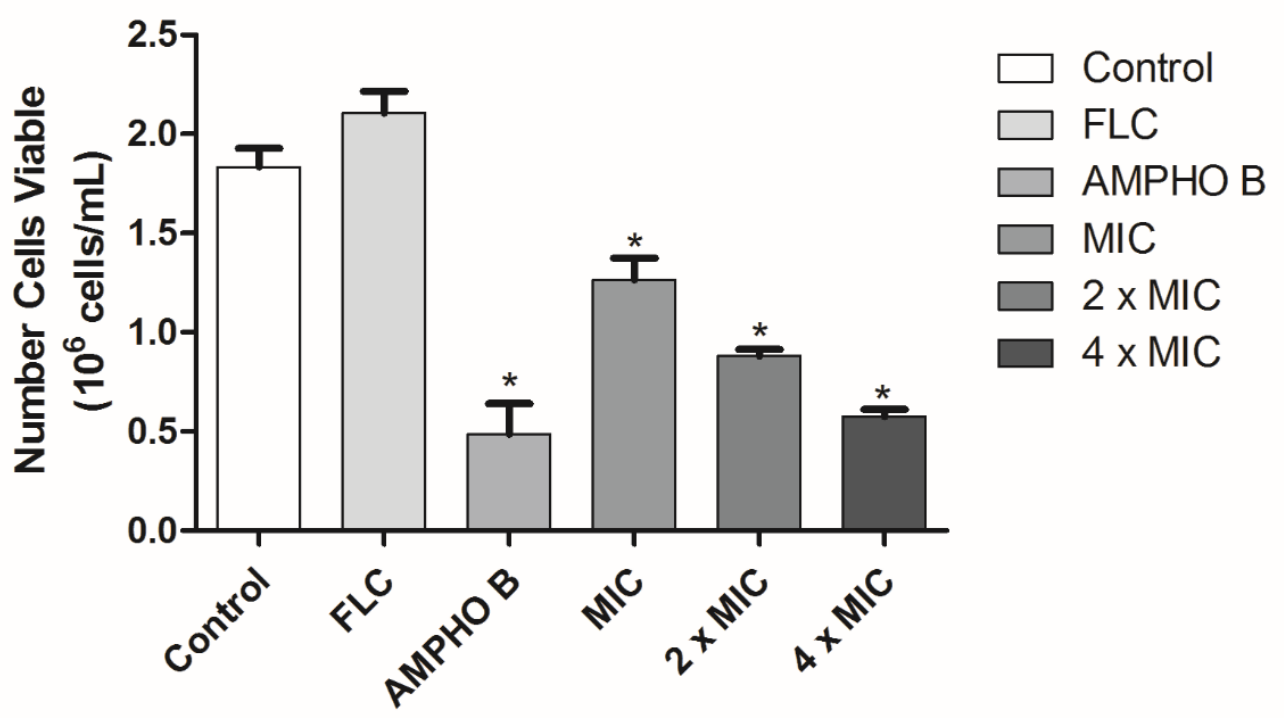

The effect of the curcumin on the cell number viable of representative FLC-resistant strain of C. albicans 
Fig.2 The cell membrane stability

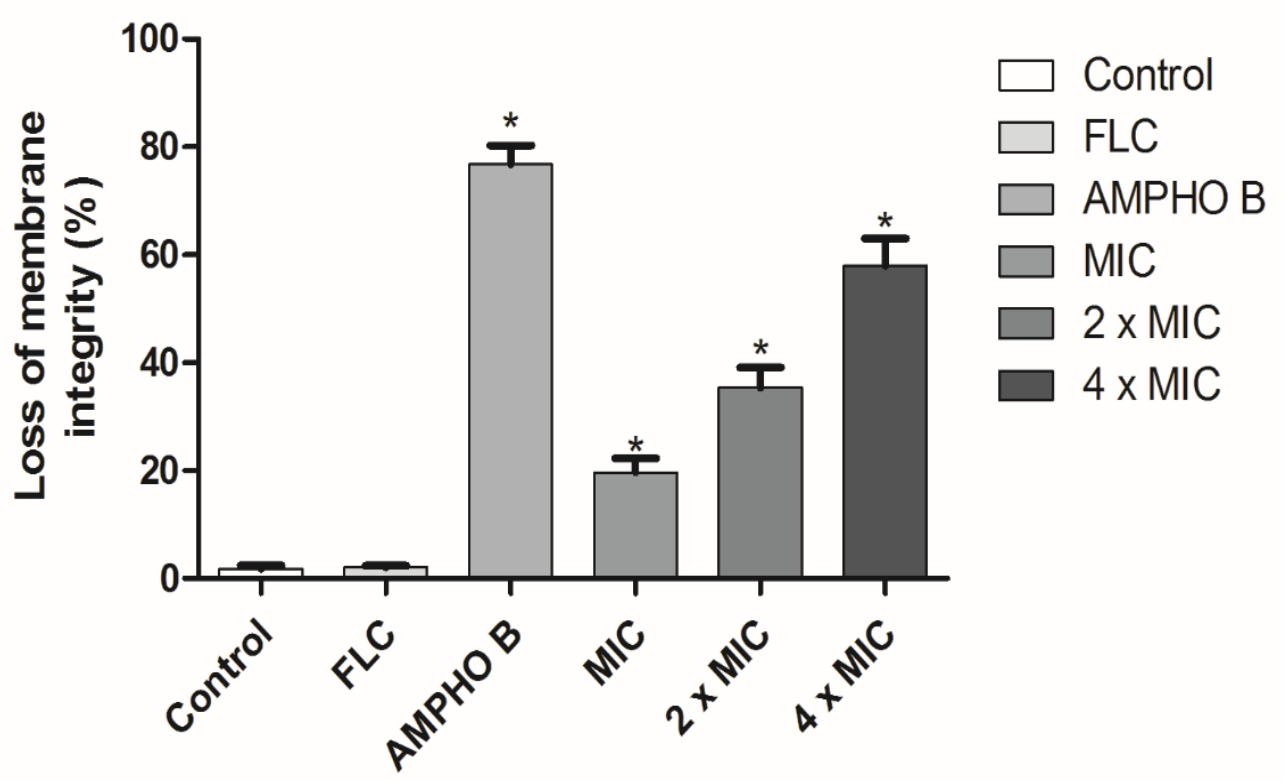

The effect of the curcumin on the cell membrane stability of FLC-resistant strains of $C$. albicans curcumin was tested at MIC, 2x MIC and 4x MIC values

Fig.3 The mitochondrial membrane potential

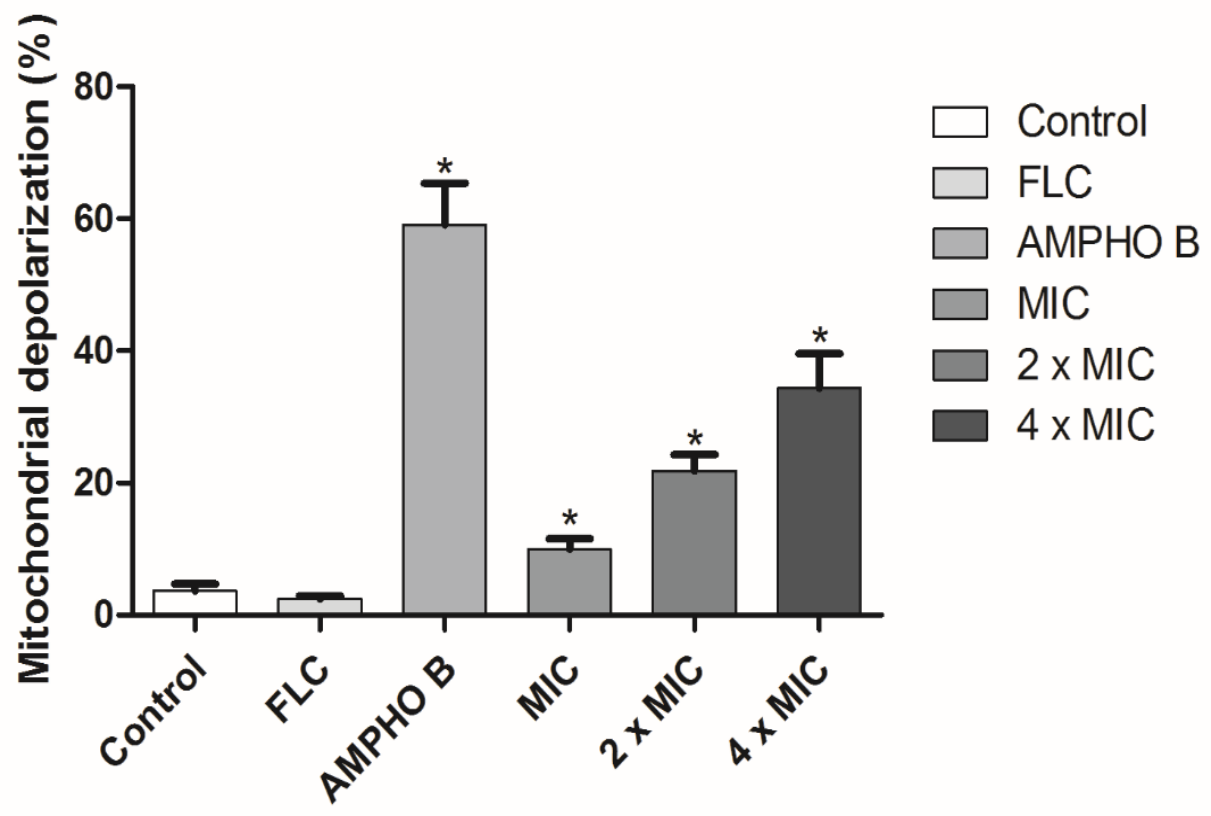

An assessment of the mitochondrial membrane potential $(\Delta \psi \mathrm{m})$ of fluconazole-resistant $C$. albicans strains. The cells were labeled with Rh123 (50 nM). The graph shows strains incubated for 24 hours with RPMI-1640 (control), with FLC $(64 \mu \mathrm{g} / \mathrm{mL})$ and Ampho $(4 \mu \mathrm{g} / \mathrm{mL})$ and curcumin at concentrations of MIC, 2x MIC and 4x MIC. The percentage of cells with mitochondrial dysfunction in the representative strains FLC-resistant of Candida spp. was evaluated for 24 hours 
Fig.4 Phosphatidyl serine externalization

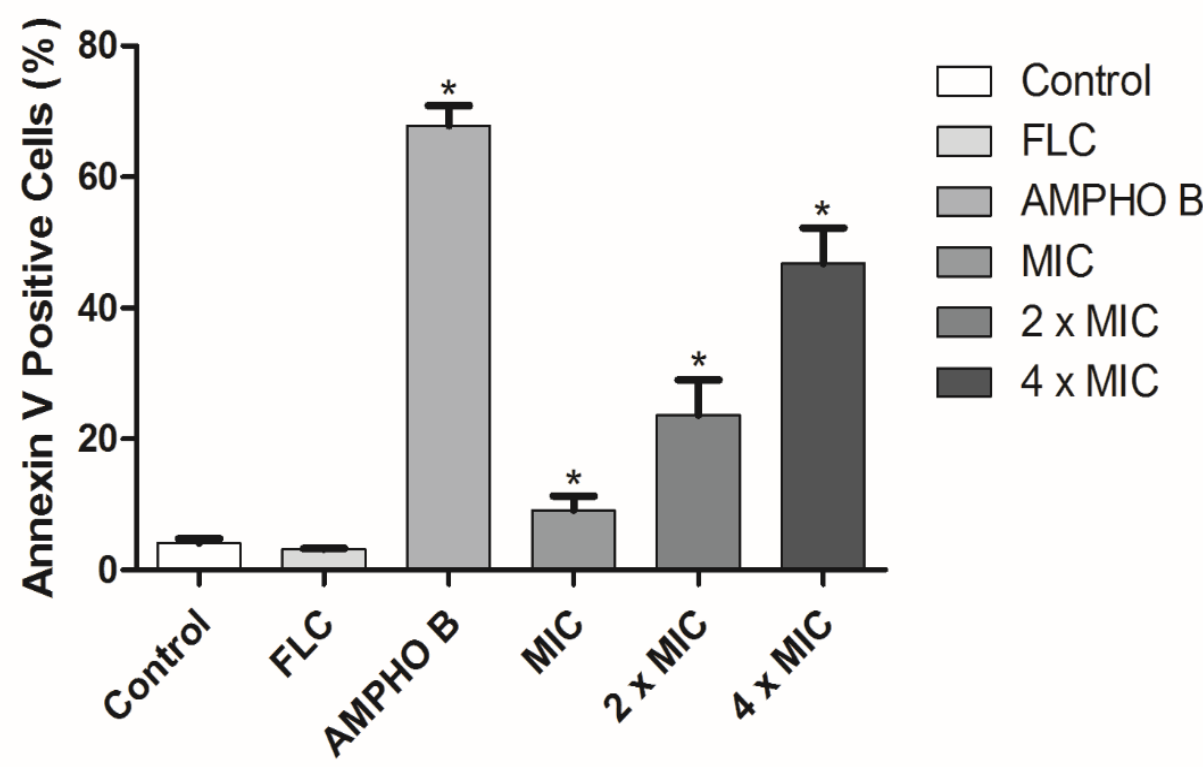

Phosphatidylserine externalization, which is observed at an early stage of apoptosis, was shown by annexin V staining. This probe enabled us to detect alterations in phosphatidylserine localization from the inner membrane to the outer membrane. The intensity of fluorescence indicates the quantity of exposed phosphatidylserine on cells treated with curcumin at concentrations of MIC, 2x MIC and 4x MIC. The percentage of Annexin $\mathrm{V}^{+}$cells in the in the representative strains FLC-resistant of $C$. albicanswas evaluated for 24 hours. ${ }^{*} \mathrm{p}<0.05$ compared to control by ANOVA followed by the Newman-Keuls test

Fig.5 Damage index in DNA

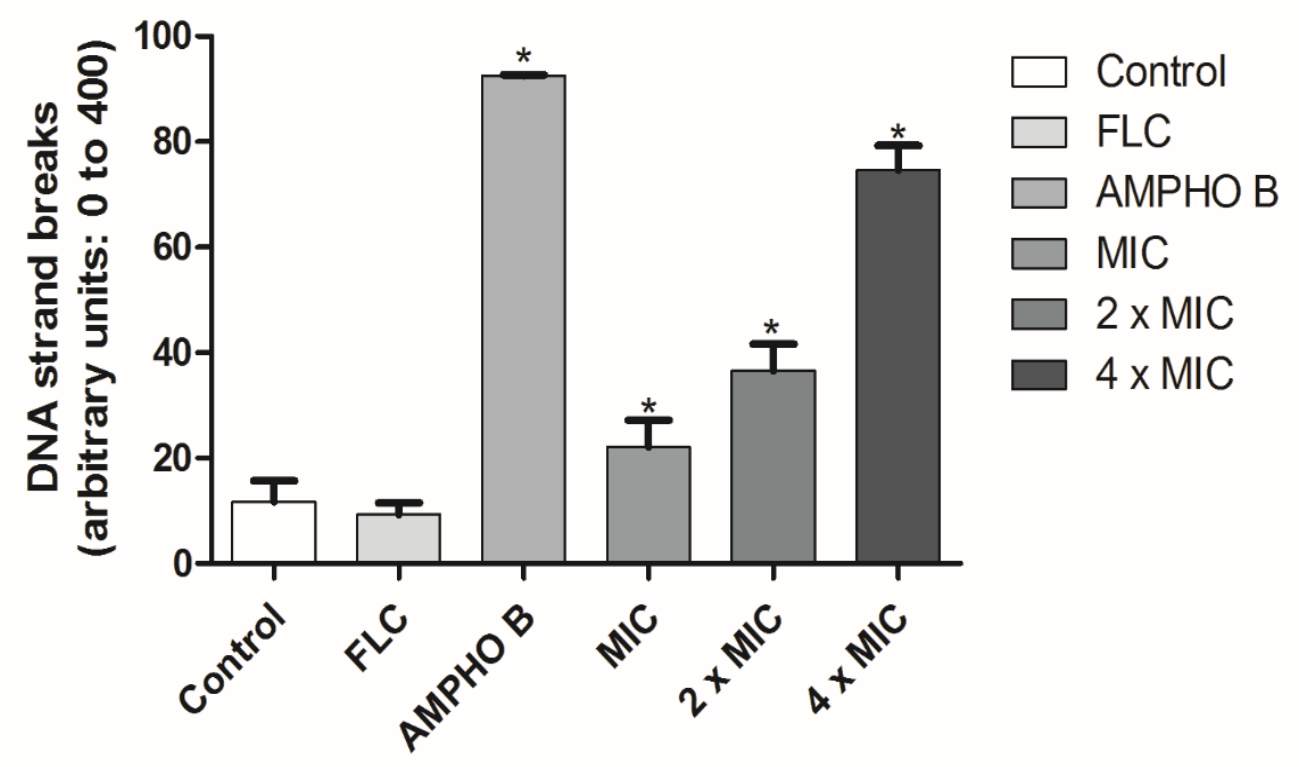

The effects of $24 \mathrm{~h}$ incubations with RPMI-1640 (control), with FLC (64 $\mu \mathrm{g} / \mathrm{mL})$, Ampho $(4 \mu \mathrm{g} / \mathrm{mL})$ and curcumin at concentrations of MIC, $2 \mathrm{x}$ MIC, $4 \mathrm{x}$ MIC on the DNA damage index in C. albicans. ${ }^{*} \mathrm{p}<0.05$ compared with the control using an ANOVA followed by the Newman-Keuls test. 
Fig.6 Damage oxidative in DNA

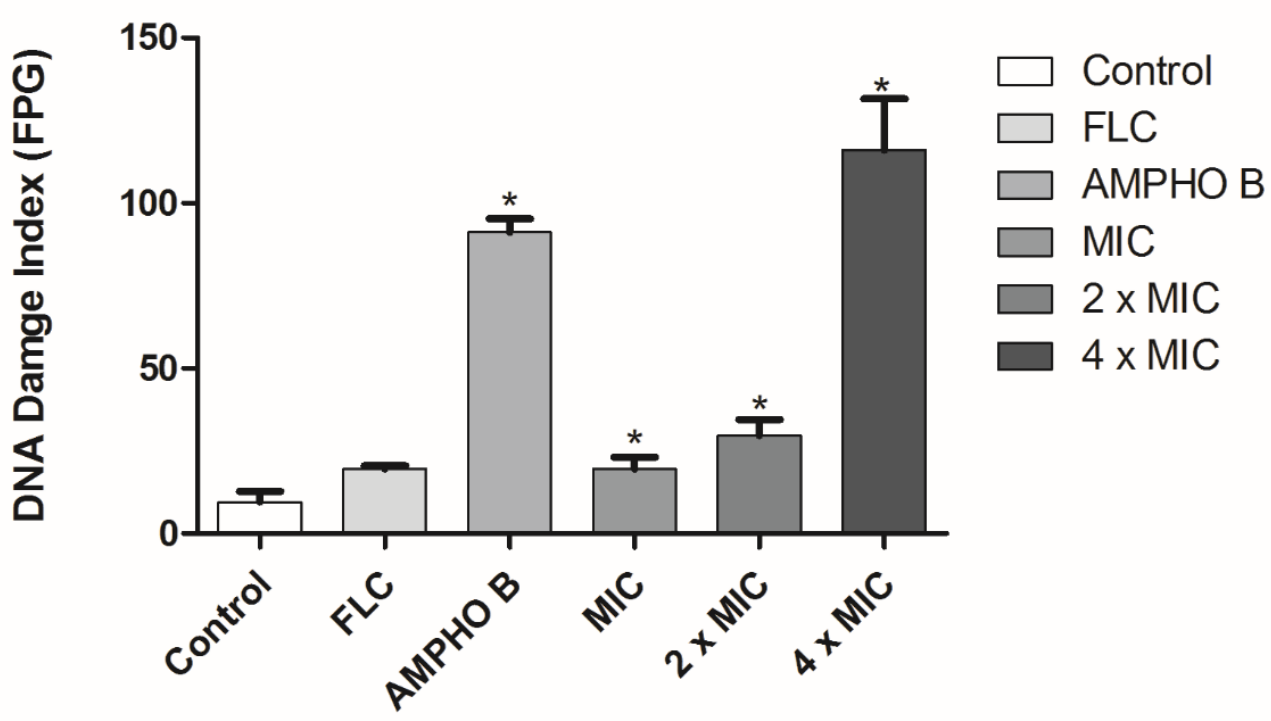

Effects of different treatments on the distribution of damage DNA classes using modified alkaline versions (FPG) of the comet assay were used in FLC-resistant strains of $C$. albicans. The yeasts were exposed to RPMI-1640 (control), with FLC $(64 \mu \mathrm{g} / \mathrm{mL})$, Ampho $(4 \mu \mathrm{g} / \mathrm{mL})$, and curcumin at concentrations of MIC, 2x MIC, 4x MIC. * p $<0.05$ compared with the control using an ANOVA followed by the Newman-Keuls test.

When the strains of $C$. albicans were treated with fluconazole, in the 24 hour period, there were no changes observed in $\Delta \psi \mathrm{m}$. However, after $24 \mathrm{~h}$ of exposure to curcumin, at different concentrations, significant changes were observed in the $\Delta \psi \mathrm{m}$ of $C$. albicans resistant to fluconazole compared to the control group ( $\mathrm{p}<0.05)$, shown in Figure 3.

Several studies on the mitochondrial functions and dynamics have been highlighting the crucial role of this organelle in biological processes, such as aging and programmed cell death (Mazzoni et al., 2013). According to Morin et al., (2011), curcumin induces an increase in mitochondrial membrane permeability, resulting in the loss of membrane potential and the inhibition of ATP synthesis, through the opening of the permeability transition pore.

Studies recently published by our group demonstrate that damage to the mitochondria is shown to be precursors of the cell death process, acting irreversibly (Andrade Neto et al., 2014; Silva et al., 2013). According to the experiments of Mahmmoud et al., (2011) and Neelofar et al., (2011), curcumin seems to act, also, inhibiting various eukaryotic ATPases, which can come to contribute to changes in the potential of mitochondrial membrane of fungi.

Our results suggest that curcumin induces apoptotic cell death in fluconazole-resistant C. albicans strains. In a study conducted by Sharma et al., (2010), curcumin induced apoptosis in strains of $C$. albicans, a fact that corroborates our findings. The apoptotic process induced by the compound curcumin is due to the activation of a transduction pathway with multiple signals (Liu et al., 2013).

In conclusion, the compound curcumin has in vitro antifungal activity against fluconazoleresistant strains of Candida spp. and Cryptococcus neoformans. Based on the 
characteristics of cell death observed, it is raised the hypothesis that curcumin seems to exert its antifungal activity at specific sites near the DNA, resulting in cell death by apoptosis. This study points to an effective biological activity of this compound, suggesting that it might be used as an adjunct to the treatment of candidemia.

\section{References}

Aggarwal, B.B. and Harikumar, K.B. 2009. Potential therapeutic effects of curcumin, the anti-inflammatory agent, against neurodegenerative, cardiovascular, pulmonary, metabolic, autoimmune and neoplastic diseases. The International Journal Biochemistry \& Cell Biology. v.41(1): 40-59.

Andrade Neto, J.B., da Silva, C.R., Neta, M.A.S., Campos, R.S, et al.,.2015. "Effects of Piperonal Nitro Derivatives on Candida species: Antifungal Activity against Fluconazole-Resistant Strains is Associated with Oxidative DNA Damage." International Journal of Current Microbiology and Applied Sciences. 4: 777-792, 2015.

Andrade Neto, J.B., da Silva, C.R., Neta, M.A.S., Campos, R.S., Siebra, J.T., Silva, R.A.C. et al., 2014. Antifungal Activity of Naphthoquinoidal Compounds In Vitro against Fluconazole-Resistant Strains of Different Candida species: A Special Emphasis on Mechanisms ofAction on Candida tropicalis. PLoS ONE. 9(5): e93698.

Azad, G.K., Singh, V., Golla, U., and Tomar, R.S. 2013. Depletion of cellular iron by curcumin leads to alteration in histone acetylation and degradation of Sml1p in Saccharomyces cerevisiae. PLoS One.8 (3): 59003.

Bergamasco, M.D., Garnica, M., Colombo, A.L., Nucci, M. 2013. Epidemiology of candidemia in patients with hematologic malignancies and solid tumours in Brazil. Mycoses. 56(3): 256-263.

Cao, J., Liu, Y., Jia, L., Zhou, H.M., Kong, Y., Yang, G., Jiang, L.P., Li, Q.J., and Zhong, L.F. 2007. Curcumin induces apoptosis through mitochondrial hyperpolarization and mtDNA damage in human hepatoma G2 cells. Free Radical Biology \& Medicine. 43(6): 968-75.

CLSI. References Method for Broth Dilution Antifungal Susceptibility Testing of Yeasts Approved Standard M27-A3. Clinical and Laboratory Standards Institute, Wayne, PA, 2008.

CLSI. Reference method for broth dilution antifungal susceptibility testing of yeasts; 4th informational supplement. CLSI document M27-S4. Clinical and Laboratory Standards Institute, Wayne, PA, 2012.

Colombo, A.L., Guimarães, T., Silva, L.R., de Almeida Monfardini, L.P., Cunha, A.K., Rady, P., Alves, T. and Rosas, R.C. 2007. Prospective observational study of candidemia in Sao Paulo, Brazil: incidence rate, epidemiology, and predictors of mortality. Infection Control and Hospital Epidemiology. 28(5): 570-576.

Da Silva, C.R., de Andrade Neto, J.B., Campos, R.S., et al., 2014. "Synergistic effect of the flavonoid catechin, quercetin, or epigallocatechingallate with fluconazole induces apoptosis in Candida tropicalis resistant to fluconazole." Antimicrobial Agents and Chemotherapy. 58(3): 1468-1478.

Da Silva, C.R., de Andrade Neto, J.B., Sidrim, J.J., Angelo, M.R., Magalhães, H.I., Cavalcanti, B.C., Brilhante, R.S., Macedo, D.S., de Moraes, M.O., Lobo, M.D., Grangeiro, T.B. and Nobre Júnior, H.V., 2013. Synergistic effects of amiodaroneandfluconazoleon 
Candida tropical is resistant to fluconazole. Antimicrob Agents Chemother. 57, 1691-1700.

Del Poeta, M., Casadevall, A. 2012. Ten challenges on Cryptococcus and cryptococcosis. Mycopathologia. 173 (5-6): 303-310.

Eisenberg, T., Carmona-Gutierrez, D. and Buttner, S. Necrosis in yeast. 2010 Apoptosis. 15 (3): 257-268.

Khan, N., Shreaz, S., Bhatia, R., Ahmad, S.I., Muralidhar, S., Manzoor, N. and Khan LA. 2012. Anticandidal activity of curcumin and methyl cinnamaldehyde. Fitoterapia. 83(3): 434-440.

Kronstad, J.W., Attarian, R., Cadieux, B., Choi, J., D'Souza, C.A., Griffiths, E.J., Geddes, J.M., Hu, G., Jung, W.H., Kretschmer, M., Saikia, S. and Wang, J. 2011. Expanding fungal pathogenesis: Cryptococcus breaks out of the opportunistic box. Nature Reviews, Microbiology. 9(3): 193-203.

Kumar, A., Dhamgaye, S., Maurya, I.K., Singh, A., Sharma, M., and Prasad, R.2014.Curcumin targets cell wall integrity via calcineurin-mediated signaling in Candida albicans.Antimicrobial Agents and Chemotherapy. 58(1): 167-175.

Liu, T.Y., Tan, Z.J., Jiang, L., Gu, J.F., Wu, X.S., Cao, Y., Li, M.L., Wu, K.J., and Liu, Y.B. 2013. Curcumin induces apoptosis in gallbladder carcinoma cell line GBC-SD cells. Cancer Cell International. 13(1): 64.

Lu, H.F., Yang, J.S., Lai, K.C., Hsu, S.C., Hsueh, S.C., Chen, Y.L., Chiang, J.H., Lu, C.C., Lo, C., Yang, M.D., and Chung, J.G. 2009. Curcumin-induced DNA damage and inhibited DNA repair genes expressions in mouse-rat hybrid retina ganglion cells [N18]. Neurochemical Research. 34(8): 14911497.
Ludwig, D.B., 2013. Dissertation [Master in Pharmaceutical Sciences]. State University of West Center. Guarapuava. Study of antifungal and cytotoxic effects of curcumin in the presence of antioxidant.

Maheshwari, R.K., Singh, A.K., Gaddipati, J. and Srimal R.C. 2006. Multiple biological activities of curcumin: a short review. Life Sciences. 27(18): 20812087.

Mahmmoud, Y.A.2011.Curcumin is a lipid dependent inhibitor of the $\mathrm{Na}, \mathrm{K}$ ATPase that likely interacts at the protein-lipid interface. Biochimica et Biophysica Acta. 1808 (1): 466-473.

Martins IMCLB. 2009. Dissertation [Masters in Oral Diagnosis]. Federal University of Paraíba, João Pessoa. Antifungal assessment Citrus limonlinn against Candida spp.

Martins, C.V., da Silva, D.L., Neres, A.T., Magalhães, T.F., Watanabe, G.A., Modolo, L.V., Sabino, A.A., de Fátima, A. andde Resende, M.A. 2008. Curcumin as a promising antifungal of clinical interest. Journal Antimicrobial and Chemotherapy. 63(2): 337-339.

Mazzoni, C., Giannattasio, S., Winderickx, J. and Ludovico, P.2013. Yeast stress, aging, and death.Oxidative Medicine and Cell Longevity. 684395.

Morin, D., Barthélémy, S., Zini, R., Labidalle, S. and Tillement, J.P. 2001. Curcumin induces the mitochondrial permeability transition pore mediated by membrane protein thiol oxidation. FEBS Letters. 495 (1-2): 131-136.

Neelofar, K., Shreaz, S., Rimple, B., Muralidhar, S., Nikhat, M., and Khan, L.A. 2011. Curcumin as a promising anticandidal of clinical. Canadian Journal of Microbiology. 57(3): 204210. 
Nucci M., Queiroz-Telles F., AlvaradoMatute T., Tiraboschi I.N., Cortes J., Zurita J., Guzman-Blanco M., Santolaya M.E., Thompson L., Sifuentes-Osornio J., Echevarria J.I. and Colombo A.L. 2013. Epidemiology of candidemia in Latin America: a laboratory-based survey. PLoSOne. 8(3):e59373.

Ogiwara, H., Ui, A., Shiotani, B., Zou, L., Yasui, A. andKohno, T. Curcumin suppresses multiple DNA damage response pathways and has potency as a sensitizer to PARP inhibitor. 2013. Carcinogenesis. 34(11): 2486-2497.

Pasqualotto, A.C., de Moraes, A.B., Zanini, R.R. and Severo LC. 2007. Analysis of independent risk factors for death among pediatric patients with candidemia and a central venous catheter in place. InfectionControland Hospital Epidemiology. 28(7): 799-804.

Passos, X.S., Costa, C.R., Araújo, C.R., Nascimento, E.S., Souza L.K., Fernandes Ode, F., Sales, W.S. and Silva, M.R. 2007. Species distribution and antifungal susceptibility patterns of Candida spp. bloodstream isolates from a Brazilian tertiary care hospital. Mycopathologia. 163(3): 145-151.
Pfaller, M.A. 2012. Antifungal drug resistance: mechanisms, epidemiology, and consequences for treatment. The American Journal Medicine. 125[1 Suppl]: S3-13.

Shaikh, J., Ankola, D.D., Beniwal, V., Singh, D., Kumar, M.N. 2009. Nanoparticle encapsulation improves oral bioavailability of curcumin by at least 9-fold when compared to curcumin administered with piperine as absorption enhancer. European Journal of Pharmaceutical Sciences. 37(3-4): 223-230.

Sharma, M., Manoharlal, R., Negi, A.S., and Prasad, R.2010. Synergistic anticandidal activity of pure polyphenol curcumin I in combination with azoles and polyenes generates reactive oxygen species leading to apoptosis. FEMS Yeast Research. 10(5): 570-578.

Sukhanova, E.I., Rogov, A.G., Severin, F.F., and Zvyagilskaya, R.A. 2012. "Phenoptosis in yeasts." Biochemistry [Moscow].77(7): 761-775.

Zhang, H., Gao, A., Li, F., Zhang, G., Ho, H.I. and Liao, W. 2009. Mechanism of action of tetrandrine, a natural inhibitor of Candida albicans drug efflux pumps. Yakugaku Zasshi. 129: 623-630.

\section{How to cite this article:}

Daniel Domingues Freitas, Cecília Rocha da Silva, João Batista de Andrade Neto, Rosana de Sousa Campos, Letícia Serpa Sampaio, Francisca Bruna Stefany Aires do Nascimento, Maria Aparecida Alexandre Josino, Lisandra Juvêncio da Silva, Helaine Almeida Queiroz, Fátima D.D. Barroso, Jacó R.L. Mesquita, Thalles Barbosa Granjeiro, Said Gonçalves da Cruz Fonseca, Bruno Coêlho Cavalcanti, Manoel Odorico de Moraes and Hélio Vitoriano Nobre Júnior. 2018. In vitro Evaluation of the Curcumin against Fluconazole-Resistant Strains of Candida spp. and Cryptococcus neoformans. Int.J.Curr.Microbiol.App.Sci. 7(04): 1191-1202. doi: https://doi.org/10.20546/ijcmas.2018.704.132 